\title{
Socio-economic Impact on Grey Parrot Survival, Implications on the Conservation of the Species in Kom National Park-Mengame Gorilla Sanctuary Complex, South-Cameroon
}

\author{
Ghislain Noé KOUGOUM PIEBENG (Correspondence) \\ Department of Biological Sciences, Faculty of Science, University of Maroua, PO Box \\ 814, Maroua, Cameroon. \\ E-mail: kougoumghislain@yahoo.fr Tel: 237-677-381-313 \\ Simon AWAFOR TAMUNGANG \\ Department of Basic Sciences, College of Technology, University of Bamenda, PO Box \\ 2164, Bamenda, Cameroon. \\ E-mail: atamungang@yahoo.com Tel: 237-677-307-655
}

Gilbert MOFOR Zechia

Department of Geography, HTTC, University of Bamenda, Bamenda, Cameroon, PO

Box 39, Bambili

E-mail: moforgz@gmail.com Tel: 237-677-067-560

\begin{abstract}
Alexis TEGUIA
Department of Physiology and Animal Production, Faculty of Agronomy and Agricultural Sciences, University of Dschang, PO Box 222, Dschang, Cameroon.

E-mail: alexisteguia@justice.com Tel: 237-677-811-137
\end{abstract}

Received: July 4, 2020 Accepted: July 26, $2020 \quad$ Published: July 30, 2020

doi:10.5296/jee.v11i2.17460 URL: https://doi.org/10.5296/jee.v11i2.17460 


\begin{abstract}
The main purpose of this study was to assess the perception of local residents regarding the impact of human activities on grey parrots (Psittacus erithacus) in Kom National Park-Mengame Gorilla Sanctuary Complex. Based on that, a structured questionnaire was administered to 400 inhabitants. The analysis shows that the capture of parrots for trade stood at $(51.50 \%)$ and mechanized logging $(68.75 \%)$. These were the greatest threats to the nest failure, nest disappearance and conservation of parrots in the complex. Among the methods of capturing birds, the most often are illegal method (74\%), the use of rifles $(12.25 \%)$ and glue traps $(27 \%)$ are the most destructive methods. Foreigners $(70 \%)$ are the most involved in the catches and no restrictions are made on the stage of development of the birds collected (eggs, chicks and adults). The living population around the complex seems to have a very low impact on the parrot resource. Strict compliance with the ban on the capture of this bird in Cameroon by CITES in 2016, afforestation or control of logging and improving the standard of living of local residents would contribute to the sustainable conservation of this species in its range.
\end{abstract}

Keywords: Grey parrot, Socio-economic, Nesting, Population, Conservation, Cameroon.

\title{
1. Introduction
}

The African Grey Parrot is widely distributed, with a range of nearly 3 million $\mathrm{km}^{2}$ from Ivory Coast and Ghana in West Africa, through Nigeria and Cameroon and the Congo forests, to Uganda and western Kenya (del Hoyo \& Collar 2014). The African grey parrot (Psittacus erithacus) is the best-known bird in the Psittacidae family, for its ability to "speak", imitate various sounds and for its intelligence (Pepperberg, 2007). It has also adapted to life in captivity and is highly valued by humans who have tamed it (Guesdon, 2010). Research has shown that it goes beyond imitation, and is probably able to communicate following reasoning (Pepperberg, 2001, 2006a), to learn to count (Pepperberg, 2006b), to classify objects and to describe them according to criteria of shape, colour, texture ... (Pepperberg, 1990). Thanks to their cognitive capacities, these birds are very appreciated on the market for companion birds and bring in significant income to the various stakeholders in this sector. This has led to an overexploitation of the species over time.

Wildlife populations worldwide are being negatively affected by the illegal wildlife trade and habitat destruction. From 1980 to the present day, grey parrots have been among the most traded of all birds listed under CITES (Convention on International Trade in Endangered Species of Wild Fauna and Flora) (2016). CITES-reported imports of grey parrots from all range countries totalled 847525 between 1980 and 2014 (http://trade.cites.org/). In Cameroon between 1981 and 2005, nearly 362,118 specimens were captured legally sold in Africa and in the other countries of the world (UNEP-WCMC CITES Trade data base, 2007). Since 2007, the grey parrot trade has been suspended again, forcing Cameroon to produce a management plan for the species, which was done by the work of Tamungang et al. (2013) which proposed an average exploitation quota of 5000 grey parrots per year. Non respect for the management plans of this species has led to the ban on the capture and marketing of this 
bird in its range (CITES, 2016). Aside from registered trade, there is significant illegal trade, including undeclared trade between the range states (Tamungang $\&$ Cheke, 2012). In addition, a high post-catch mortality of these birds, of the order of 30 to $40 \%$, is observed during transport from the places of capture to the cities, then to the consuming countries and dead birds are not counted by the exporters (Ngenyi, 2002).

This strong commercial exploitation is coupled with an extensive degradation of their habitat following by anthropic activities such as: agriculture, hunting, urbanization, logging and mining which lead to the disappearance of nests in a natural environment (Tamungang \& Cheke, 2012; Kougoum et al., 2017), grey parrots are strongly associated with tropical forests in Africa. The immediate consequence of these activities is the decline in the population of grey parrots and in particular sexually mature couples, which leads to a decrease in reproduction which can even lead to the extinction of the species (Tamungang et al., 2002). Indeed, these activities lead to the abandonment of grey parrot nests, their disappearance and a change in the characteristics of the habitat which affect the overall success of reproduction (Kougoum et al., 2017).

Numerous studies have already been carried out on African grey parrots, including inventories, the characterization of their habitat, their diet and the study of reproduction. This work aims to assess the perception of residents of the Kom National Park complex (KNP) -Mengame Gorilla Sanctuary (MGS), of the impact of socioeconomic activities on the survival and conservation of grey parrot (Psittacus erithacus).

\section{Materials and Methods}

\subsection{The Study Area}

The KNP-MGS complex is located between latitudes $2^{\circ} 15^{\prime \prime}$ 'and $2^{\circ} 25^{\prime \prime}$ North; and longitudes $11^{\circ} 40^{\prime \prime}$ and $12^{\circ} 42^{\prime \prime}$ 'East. It covers an area of about $958 \mathrm{~km}^{2}$ found in the lowland rainforest of the Congo Basin. The complex is rich in species diversity, composed of many types of sub-ecosystems (evergreen rainforest, swamp forests, raffia palm forests, and secondary forests) (Nkongmeneck et al., 2003). The Complex is bordered to the South by Kom River which is the natural border between Cameroon and Gabon, to the North by Mvangane and Oveng Sub-Divisions, to the West by Lobo River and to East by Djoum Sub-division (Figure 1).

The study area had an average annual temperature of about $24^{\circ} \mathrm{C}$ and the rainfall from 1500 to $2000 \mathrm{~mm}$. It usually rains throughout the year with two maxima: in September to October (long rainy season) and March to April (short rainy season). The minima occur in December to January (long dry season) and July to August (short dry season) (Data from the Sangmelima Meteorological Center, 2012).

The population of the study area is estimated at more than 9000 inhabitants distributed in 35 residential communities and the average density is less than 4 inhabitants $/ \mathrm{km}^{2}$ (Ngoufo \& Njoumeni, 2012). The populations of the study area practice agriculture (food and cash crops), animal husbandry, trade, hunting, gathering and handicrafts. 


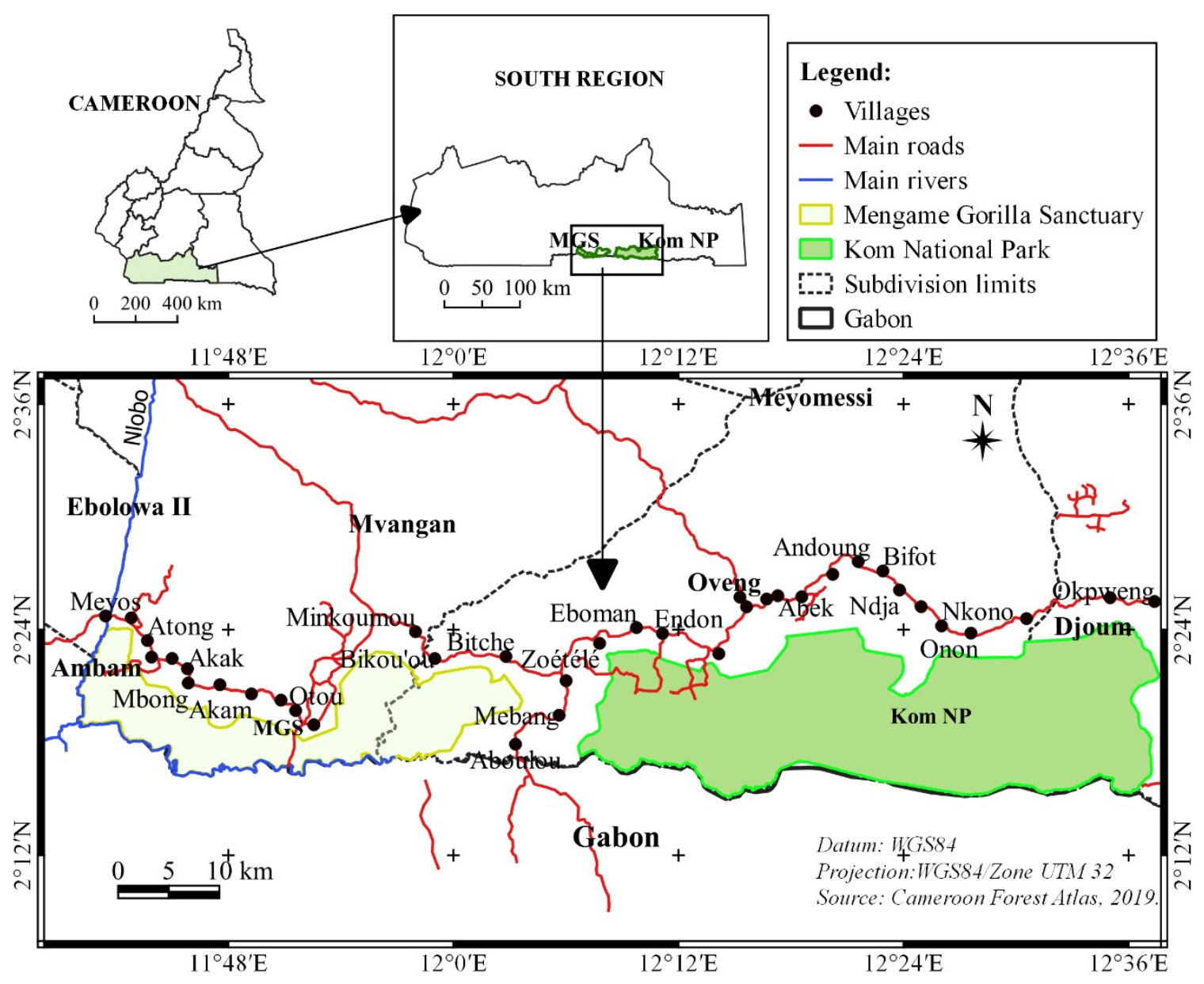

Figure 1. Location of the study area

\subsection{Methods}

The field survey was carried out between 2010 and 2011 using a structured questionnaire administered to people living near forest areas (Complex). Prior meetings were organized with the village chiefs and the villagers to explain the merits of our work. Local translators (02) and two field assistants were recruited for the two survey teams. They allowed us respectively, to make a rapid collection of information and to facilitate exchanges.

The administration of the questionnaire to residents made it possible to assess the influence of socio-economic activities on nesting and the population of grey parrots such as: the characteristics of the population (gender, age, sex) and activities of the respondent (fishermen, traders, farmers, hunters and traffickers); forest degradation (agriculture, logging and mining, road construction, etc.); patterns of use of grey parrots in the study area (domestication, marketing, hat decoration, traditional practices, treatment of diseases, etc.); hunting, whether legal or illegal; origin of traffickers; method of capture (glue trap, wire trap, net, rifle, grenade, 
anaesthetics, climbing nests); catching parrots (catching period, catching age, number, type of cage for transport and mode of transport) and marketing channels (routes, cities and countries of destination).

The following formula allowed us to calculate the sample size, with a confidence level of $95 \%$ and a maximum variability of 50\% (Yamane, 1967) and reviewed by Israel (2012): $\mathbf{n}=\mathbf{N} /(\mathbf{1}+$ $\left.\mathbf{N}\left(\mathbf{e}^{2}\right)\right)$; Where ' $\mathrm{n}$ ' is the sample size, ' $\mathrm{N}$ ' is the population size (9000 inhabitants) and ' $\mathrm{e}$ ' is the level of precision $(0,05) . n=9000 /\left(1+9000 \times(0,05)^{2}\right)$; therefore $n=383$. On this basis, a total of 400 questionnaires were administered to local residents.

For data collection, we carried out a non-proportional stratified random sampling. To this end, sixteen (16) villages were chosen at random from the 35 residential communities in the study area. Thus, the following localities were chosen: Oveng centre, Ngwassa, Akom I, Mvam II, Andoung, Endone, Ebomane, Akoabas, Mebang, Bitché, Bikououk, Mengame, Amvom, Aboumezok, Mebosso and Meyos. The questionnaire was sent to everyone (eco-guards, post chiefs of forest, conservator, cultivators, breeders, traders, hunters and fishermen) regardless of gender and aged at least 15 years and resident in the locality. At least 20 people were interviewed in each selected locality. The questionnaire was administered to only one person at a time and preferably in the afternoons.

\subsection{Data Analysis}

The data analysis was carried out using GraphPad InStat version 3.00 and STATGRAPHIC Centurion version XVI.I Descriptive statistics were used to compute requencies, percentages, and other important information. Chi-square test was conducted to test the relationship between the perception of respondents and different variables related to the demographic and socio-economic characteristics of the respondents. When the observed frequencies were less than 5, Fisher's exact test was used to compare the values of the rows and columns in pairs. The probability threshold used was $\mathrm{p}=0.05$.

\section{Results and Discussion}

\subsection{Results}

\subsubsection{Demographic and Socio-economic Characteristics of Respondents}

Of the 400 respondents, $312(78 \%)$ were males while the rest $88(22 \%)$ were female. The average age of respondents was 44.18 years, with a range from 15 to 80 years. The middle age group (40 to 59) comprises $(54.50 \%)$ of the respondents (Table 1). Most of the respondents (39\%) were illiterate (can neither read nor write), the rest of the $61 \%$ of respondents knew how to read and write, they had at least a primary education. Crop farming $(41.50 \%)$ and the hunting (19.25\%) were the main sources of income for local communities around the KNP-MGS complex. Here parrot operator designates those who, directly or indirectly, are involved in catching and marketing parrots. In the villages their activities are limited to guiding, transporting, building quarantines in the forest or in the vicinity of the villages. 
Table 1. Socioeconomic and demographic characteristics of respondents

\begin{tabular}{lll}
\hline Variables & Frequency & Percentage \\
\hline Gender & 312 & 78.00 \\
Male & 88 & 22.00 \\
Female & & \\
\hline Age class & 117 & 29.25 \\
$15-39$ & 218 & 54.50 \\
$40-59$ & 65 & 16.25 \\
$\geq 60$ & & \\
Education level & 156 & 39.00 \\
Illiterate & 124 & 31.00 \\
Primary & 102 & 25.50 \\
Secondary & 18 & 4.50 \\
Higher & & \\
\hline Main occupation & 34 & 8.50 \\
Fisherman & 66 & 16.50 \\
Trader & 166 & 41.50 \\
Farmer & 77 & 19.25 \\
Hunter & 49 & 12.25 \\
Livestock & 8 & 2.00 \\
Parrot operator & & \\
\hline
\end{tabular}

3.1.2 Peasant Perception of the Impact of Socio-economic Activities on the Nesting Success of Grey Parrots

When asked, what are the main socioeconomic activities that impact nest success, $46 \%$ of respondents think that mechanized logging is by far the main cause of nest failure, followed by the capture of birds for the marketing (27\%). Agriculture (14\%) and artisanal logging (6\%) of wood (cutting down trees for making works of art, building huts and various objects). Other causes such as: natural predation (2.5\%) (raptors, snakes, monkeys, etc.), slaughter for the collection of firewood (1.5\%) and the capture of nestlings in the nest (1.25\%) seems not have a great impact on the nesting success of grey parrots. 


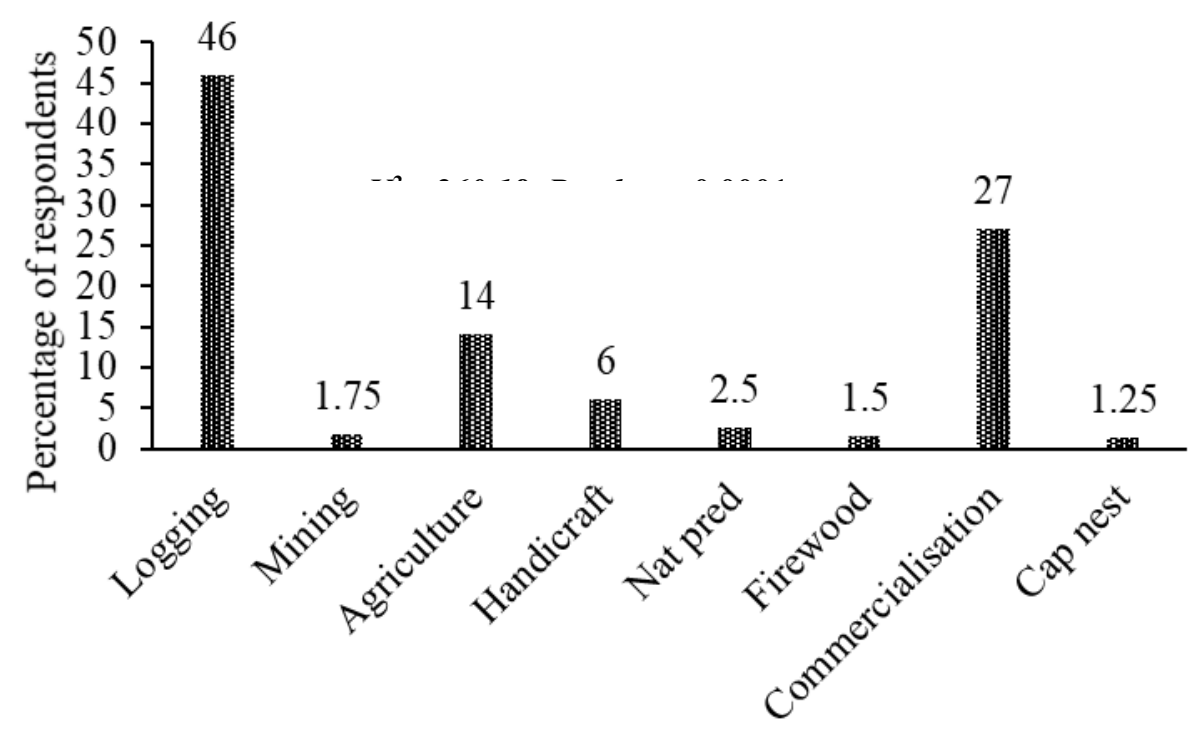

Nat pred $=$ Natural predation; Cap nest $=$ Capture in the nest .

Figure 2. Impact of human activities on nesting success of grey parrot

\subsubsection{Peasant Perception of the Causes of the Disappearance of Nests in the Study Area}

Table 2 presents the peasant perception of the causes of the disappearance of grey parrot's nests.

Table 2. Impact of human activities on the disappearance of grey parrot's nests.

\begin{tabular}{|c|c|c|c|c|c|c|}
\hline \multirow{2}{*}{ Variables } & \multirow{2}{*}{$\mathbf{n}$} & \multicolumn{2}{|c|}{ Effect on nests disappearance } & \multirow{2}{*}{ df } & \multirow{2}{*}{$X^{2}$} & \multirow{2}{*}{ P-value } \\
\hline & & Yes & No & & & \\
\hline \multicolumn{7}{|c|}{ Human activities } \\
\hline Agriculture & 69 & 8 & 61 & \multirow{4}{*}{3} & \multirow{4}{*}{240.54} & \multirow{4}{*}{$<0.0001$} \\
\hline Handicraft & 27 & 9 & 22 & & & \\
\hline Logging & 295 & 275 & 20 & & & \\
\hline Mining & 9 & 8 & 1 & & & \\
\hline
\end{tabular}

$n=$ number of respondents; $d f=$ degree of freedom; $X^{2}=$ Chi-square.

When asked which human activities are most responsible for the disappearance of parrot nests in the study area, $68.75 \%(n=275)$ of residents say that mechanized logging is the most destructive (Table 2). On the other hand, the creation of plots for agriculture $(2 \% ; n=8)$, the artisanal cutting of woody trees $(2.25 \%)$ and mining $(2 \% ; n=8)$ seem to not pose any serious threat to nesting parrots. A significant difference was noted between the different deforestation rates on the disappearance of the nests $\left(X^{2}=240.54\right.$; $\left.d f=3 ; p<0.0001\right)$. 


\subsubsection{Perception of LOCAL RESIdents on the USe of GREY PARrots}

Table 3 below presents the types of use of grey parrot after capture.

Table 3. Perception of respondents on parrot utilisation

\begin{tabular}{lllllllllll}
\hline Variable & \multicolumn{8}{c}{ Perception of respondents on parrot utilisation (Frequency) } \\
& $\mathbf{n}$ & Trading & Domest & Tra U & Nutri & Others & df & $\boldsymbol{X}^{\mathbf{2}}$ & P-value \\
\hline Gender & & & & & & & & & \\
Male & 312 & $\mathbf{1 7 2}$ & 62 & 50 & 20 & 8 & 4 & 9.243 & 0.055 \\
Female & 88 & 34 & 21 & 18 & 10 & 5 & & & \\
\hline Age class & & & & & & & & & \\
$15-39$ & 117 & 75 & 22 & 11 & 6 & 3 & & & \\
$40-59$ & 218 & $\mathbf{1 0 7}$ & 51 & 39 & 16 & 5 & 8 & 26.275 & $\mathbf{0 . 0 0 0 9}$ \\
$\geq 60$ & 65 & 24 & 10 & 18 & 8 & 5 & & & \\
\hline Education level & & & & & & & & \\
Illiterate & 156 & 71 & 41 & 26 & 12 & 6 & & & \\
Primary & 124 & 67 & 20 & 23 & 9 & 5 & 12 & 13.603 & 0.3267 \\
Secondary & 102 & 60 & 17 & 18 & 6 & 1 & & & \\
Higher & 18 & 8 & 5 & 1 & 3 & 1 & & \\
\hline
\end{tabular}

$n=$ number of respondents; Domest=domestication; Tra U= Traditional use; Nutri = nutrition (alimentation); $d f=$ degree of freedom; $X^{2}=$ Chi-square

No significant difference was observed between the perception of the residents on the modes of parrots use and the genus on the one hand $\left(X^{2}=9.243 ; d f=4 ; p=0.055\right)$; and between the level of education on the other hand $\left(X^{2}=13.603 ; d f=12 ; p=0.3267\right)$. However, a significant difference $\left(X^{2}=26.275 ; d f=8 ; p=0.0009\right)$ was observed between the perception of local residents on the methods of using parrots and the different age classes. It appears from the table 3 that most of the parrots captured are intended for trade $(51.50 \% ; \mathrm{n}=206)$. These birds are also used as companion birds $(20.75 \% ; \mathrm{n}=83)$ and in traditional ceremonies $(17 \% ; \mathrm{n}=68)$. Very few GPs are consumed $(7.5 \% ; \mathrm{n}=30)$ by the villagers. Culturally and traditionally, the red feathers of the parrot's tail are placed on the hats of chiefs or great personalities for distinction and honour. They are also used to fight against witchcraft and the treatment of certain diseases. Domestication and traditional use do not appear to pose a threat to the grey parrot population. According to local residents for the feather to have power in the tradition, they must be collected in the forest (feeding site, dormitory, around the nests) and not come from a slaughtered bird. Capture for marketing poses a great threat to this species of Psittacidae. Indeed, by this operation, the hundreds, even thousands of individuals are taken from the wild without taking into account the rate of renewal of the population. 


\subsubsection{Capture Methods and Influence on the Health Status of Parrots}

The capture methods used are sometimes violent and very destructive. Table 4 presents the different methods used to capture parrots in the study area and the influence of each of these methods on the health state of birds.

Table 4. Perception of respondents about the impact of different methods of capture on the health state of parrots

\begin{tabular}{|c|c|c|c|c|c|c|}
\hline \multirow[t]{2}{*}{ Variables } & \multirow{2}{*}{$\mathbf{n}$} & \multicolumn{2}{|c|}{ Impact on health state of parrots } & \multirow{2}{*}{$-\mathbf{d f}$} & \multirow{2}{*}{$X^{2}$} & \multirow{2}{*}{ P-value } \\
\hline & & Yes & No & & & \\
\hline \multicolumn{7}{|c|}{ Methods of parrot capture } \\
\hline Anaesthetic & 10 & 8 & 2 & \multirow{6}{*}{5} & \multirow{6}{*}{105.73} & \multirow{6}{*}{$<0.0001$} \\
\hline Nest climbing & 14 & 4 & 10 & & & \\
\hline Net & 21 & 5 & 16 & & & \\
\hline Rifle & 49 & 49 & 0 & & & \\
\hline Glue trap & 173 & 108 & 65 & & & \\
\hline Wire trap & 82 & 14 & 68 & & & \\
\hline No idea & 51 & 1 & 1 & & & \\
\hline
\end{tabular}

$n=$ number of respondents; $d f=$ degree of freedom; $X^{2}=$ Chi-square

The number of people $(12.75 \% ; \mathrm{n}=51)$ who had no idea about the capture methods was not taken into account in the statistical analyses. Table 4 shows the frequencies of use of the different capture methods. According to residents, there are six methods of catching parrots in the study area. Glue traps $(43.25 \% ; n=173)$, followed by wire traps $(20.50 \% ; n=82)$ and rifles $(12.25 \% ; \mathrm{n}=49)$ are the most common capture methods used while tree climbing, the use of nets and anaesthetics are less practiced. A significant difference $\left(X^{2}=105.73 ; d f=5 ; p\right.$ $<0.0001$ ) was observed regarding the impact of the capture method on the health status of the birds. The use of anaesthetics $(2 \% ; n=8)$, guns $(n=49)$ and glue traps $(27 \% ; n=108)$ have the greatest negative impact on the state of health of parrots.

\subsubsection{Origin of Trappers and Age of Parrot Capture}

Figure 3 below shows the origin of the trappers and the age from which the parrots are caught in the study area. This figure shows that it is foreign people in the study area who capture the most parrots $(70 \%)$. A significant difference $\left(X^{2}=8.123 ; d f=2 ; p=0.0044\right)$ was therefore observed between the origins of the trappers. These foreigners are mainly Cameroonians from other regions (Centre and North-West) who operate in the capture of parrots, generally with the collaboration of villagers. Foreigners of other nationalities are sometimes noted, these are Nigerians and Ghanaians. 


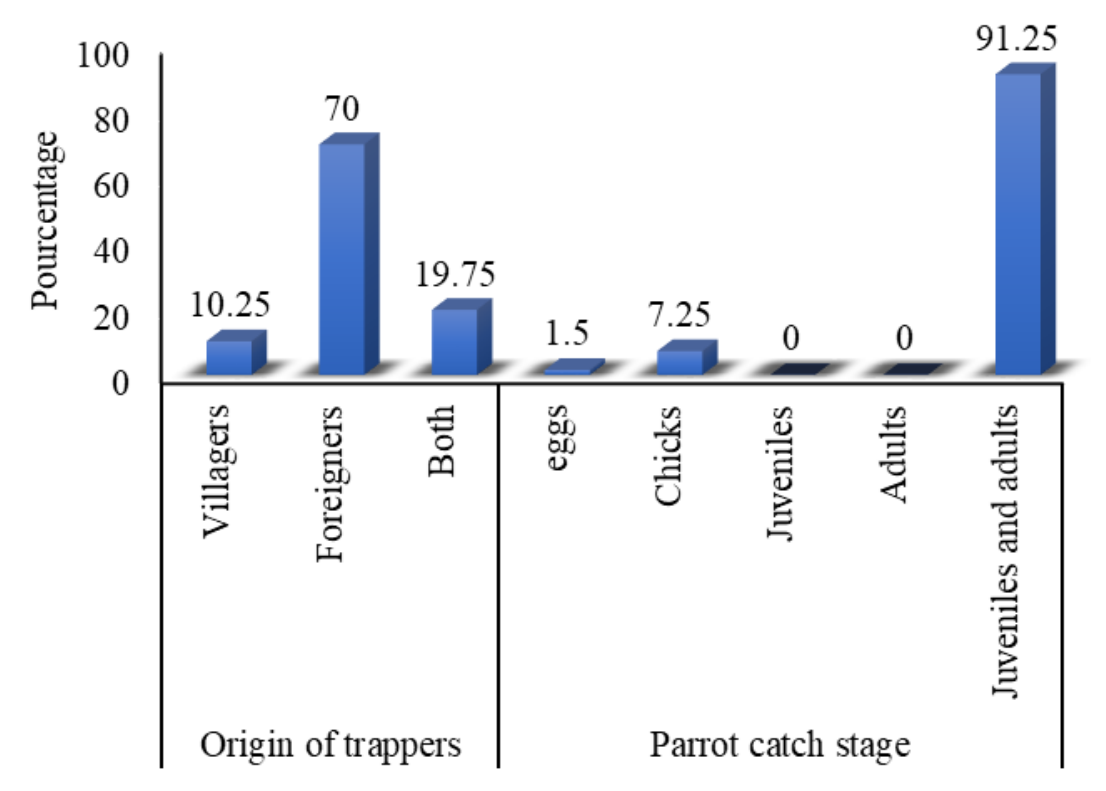

Figure 3. Origin of trappers and parrot catch stage

Parrots are caught regardless of the age of the birds. Young and adults are the most captured $(91.25 \%)$, followed by nestlings $(7.25 \%)$ and finally by collecting eggs from the nest $(1.5 \%)$. All available or fallen birds are caught without distinction. Very few residents claim to have seen people catching nestlings and, rarer still, collecting eggs in nests. A significant difference $\left(X^{2}=908.65 ; d f=2 ; p<0.0001\right)$ was observed between the different stages of parrot capture. Most of the chicks captured are those that fell naturally from the nests or were victims of predation.

\subsubsection{Types of Hunting Used to Catch Parrots}

The type of hunting used to catch grey parrots with red tails is both legal and illegal. Figure 3 shows the types of hunting practiced in the study area.

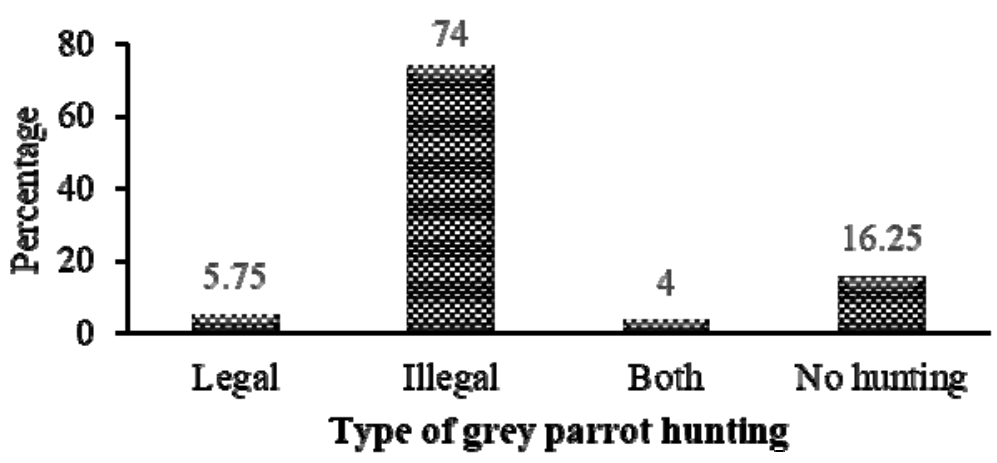

Figure 3. Peasant perception of the type of grey parrot hunting 
Surveys of people living near the study area show that $74 \%$ of illegal hunting (without a capture permit) is practiced, compared to $6 \%$ for legal hunting, $4 \%$ of villagers say that hunting is done both legally and illegally and finally $16 \%$ of them affirm the nonexistence of grey parrot capture activities in their village. A significant difference was observed in the residents' perception of the type of hunting practiced in the study area $\left(X^{2}=701.68 ; d f=3 ; p<0.0001\right)$.

\subsubsection{Transport of Parrots and Marketing Circuit in the Study Area}

Note that this study was carried out before the suspension of parrot trade in Cameroon. In fact, since 2016, the grey parrot has been placed in Appendix I of CITES. Therefore, trade in live, dead specimens and their parts is now prohibited. In the study area, parrots captured in their natural environment are first stored in cages made with plant material while the capture continues. At the end of the capture, the birds are transported in large numbers in wooden cases or in baskets either directly to the cities, or in the villages where they can stay another few days in quarantine before being transported to the cities. Some traffickers buy parrots directly from villagers for 5,000 "francs" per bird. This price often varies between 5,000 and 15,000 "frs CFA" depending on the residents involved in one of the parrot marketing channels.

These birds are also transported in small numbers in bags, boxes and small baskets. The illegal transport of birds is preferably done at night and sometimes during the day using motorcycles, private vehicles, public transport vehicles, on canoes and even on foot in border areas with Gabon or the Equatorial Guinea.

The marketing channels concern catches with agreement as well as illegal ones. The parrots captured in the KNP are transported by road initially to the subdivisions of Djoum and Oveng, then transported to Sangmelima, then to the major cities (Yaounde and Douala) where part will be sold to individuals, the rest will finally be shipped to foreign countries (Africa, USA, Asia and Europe). Birds also from KNP are transported to Gabon through forest tracks. They also pass through the Mvangane subdivision, then Ebolowa from where they will be taken to major cities before leaving the country.

The birds captured in the MGS transit mainly through Mvangane, then the big cities before ending up abroad. Another part of these birds is fraudulently transported to Gabon or Equatorial Guinea where they will be sold as resident parrots.

\subsubsection{Evolution of the Parrot Population Over Time}

Figure 4 shows the perception of local residents regarding the status of grey parrots in the study area. This figure shows that the number of grey parrots has diminished over time, which represents $41 \%(n=163)$ of the sampled population, $28 \%$ think that the parrot population is stable over time and $19 \%$ think that it is difficult to estimate the number of birds. Only $12 \%$ of residents believe that the parrot population has increased over time. 


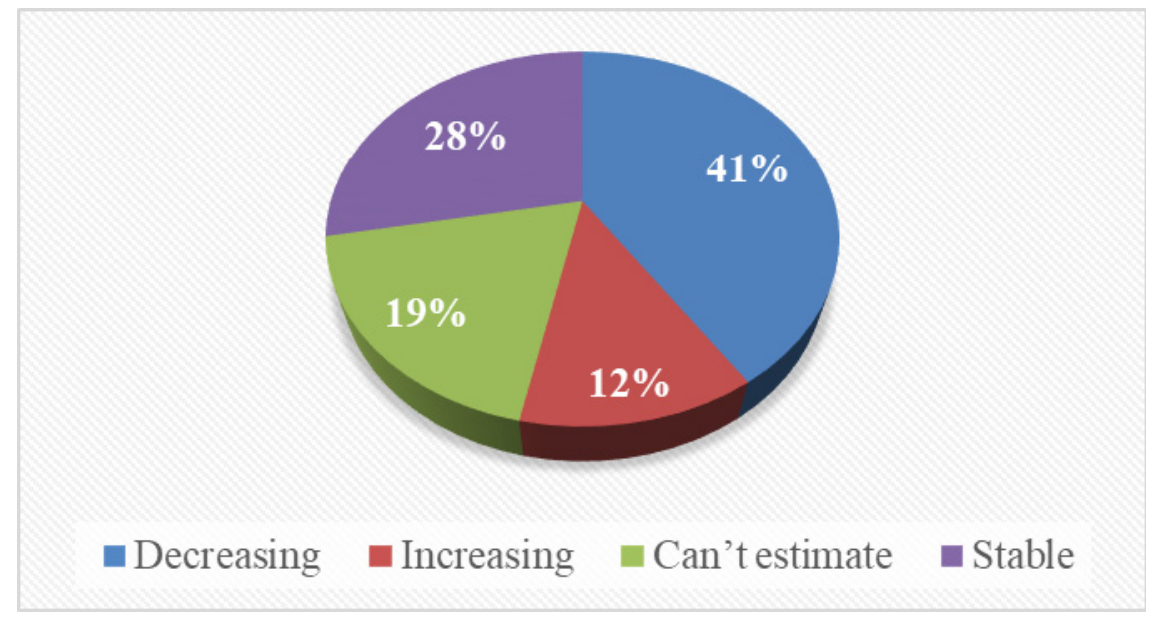

Figure 4. Population status of grey parrots in the study area

\section{Discussion}

\subsection{Use of Grey Parrots and Influence of the Capture Method on Their Population}

Grey parrots in the study area are most caught for marketing. This mode of use of the parrot has a great impact on the population of these birds, in particular their reduction in the natural environment. Indeed, it has already been shown that catches for the trade in wild birds is one of the causes of population declines in Cameroon and in the other countries of its range (CITES, 2016).

In conjunction with collection for the pet trade, the loss of forests and fragmentation over the past 30 years have had an impact on the population by reducing the available breeding and feeding habitats for grey parrots (Tamungang et al., 2013; Annorbah et al., 2016). The other types of use (domestication, traditional use, source of protein) of grey parrot at the local level seem to have a low impact on the population of these birds. In fact, the majority of parrots domesticated in the locality are those collected in the forest (injured birds) or young chicks that have fallen from the nest (Kougoum et al., 2017). The red feathers of the parrots' tail, according to the villagers, to be effective in tradition or in the practice of magic must be those picked up from the ground and not those torn from birds caught or slaughtered. Consumption of parrots as a source of animal protein in the study area is accidental, it is not systematic and therefore has no significant effect on the parrot population. In other areas of the grey parrot range, the domestic (consumption) and traditional use of the parts (heads, legs and red feathers) of these birds in medicine and the practice of black magic have a significant impact on the population of the species (Tamungang \& Cheke, 2012; Collar et al., 2016). The growing demand from parts of this bird is pushing traffickers to capture an increasing number of parrots. The only documented cases of capture of grey parrots for their body parts have been in Lobeke National Park, Cameroon, with the repeated arrests of the same poacher found with parrot heads and organs (Tamungang \& Cheke, 2012; CITES, 2016). 
Most methods of capturing (rifle, glue trap and anaesthetic) the grey parrot in the study area are destructive. Glue traps are the most used for catching birds. In fact, in this region, most parrots generally sleep perched in forest trees or trees bordering streams, which makes the use of glue very effective. But this method has a very negative influence on the general health of the birds, many die sometime after capture, those who manage to escape are an easy target for predators (May, 2001). The mortality of this species, from capture to export to Cameroon is estimated between 30 and 50\% (Fotso, 1998a). Assuming a mortality rate of 40\% 60\% between capture and export, the total number of birds captured to feed all legal trade in its range is probably in the range of 2.1 to 2,500 000 since 1975 (CITES, 2016). Many local residents find it useless to use guns to kill a simple parrot, which does not represent much in terms of animal protein intake. Some use rifles to kill parrots which devastate their plantations (palm groves) and fruit trees (case of sausage trees) or cut them down on command for their red feathers.

\subsection{Impact of Socio-economic Activities on the Success of Parrot Nesting}

Deforestation in general, and logging in particular, is the one that causes the most failure in the nesting of grey parrots. Indeed, these birds do not build nests, but reproduce in the cavities formed naturally in the trunks or branches of large forest trees (Kougoum, 2016 and 2017). This nest resource is thus limited in time and space. Culling of nests, destruction of eggs, death of nestlings and abandonment of the nesting site and reduction of nesting success. As for marketing, it entails the capture of couples during the nesting period, which leaves the nests unprotected and the chicks without parental care. This inevitably leads to their death and the failure to nest.

\subsection{Origin of Trappers and Stage of Parrot Capture}

The parrot trappers in the study area are mainly people outside the study area because the populations living near the study area do not generally attach great economic importance to these birds. Indeed, the contribution of local residents in traffic comes down to accommodation, providing information on the areas where parrots are encountered and accompanying trappers in the forest. In return; they receive drinks, cigarettes, money or ammunition for hunting. This cooperation between traffickers and villagers promotes the illegal hunting of parrots. Parrot trappers are foreigners from foreign cities and countries who have a perfect understanding of the economic value of grey parrots, which is not the case for the villagers.

All stages of parrot development (eggs, nestlings, young and adults) in the study area are exploited by traffickers, which has an impact on their population. Indeed, this non-selective capture (capture of breeders) leads to the abandonment of nests by some trapped couples. This abandonment of the nests, in turn, leads to the cessation of the development of eggs in the nests and the death of abandoned young birds to their own fate. The removal of eggs and nestlings from nests by local residents also has the same consequences. This results in a reduction in nesting success in the study area. 


\subsection{Types of Hunting Practiced and Marketing Channel}

The illegal hunting of grey parrot is the most practiced in the study area. This for several reasons: the existence of bypasses for forest control posts; ignorance of the texts in force regulating the parrot traffic, the poverty of local residents and the porous borders between Cameroon, Gabon and Equatorial Guinea. This favour the capture of a very large number of birds which are not declared in international grey parrot trade. P. erithacus is the subject of a significant illegal trade which can be done under the cover of a legal trade (with falsified or fraudulent CITES permits) or clandestine expeditions, or with false identifications of wild birds as birds bred in captivity (CITES, 2016). In recent years, several range states have reported significant exports of captive-bred specimens (CITES source code "C") despite the lack of breeding operations in these countries. This was the case between 2008 and 2013, where approximately 7,266 specimens of $P$. erithacus were reported with a "C" code in Guinea, Central African Republic, DRC, Ivory Coast, Liberia, Cameroon and DRC (CITES, 2016).

Legal hunting in the range countries for which export quotas are currently set (DRC and Cameroon), the use of fraudulent or copied permits is widespread. The quantities declared by importers are regularly above export quotas and are said to exceed the number of export permits issued by range countries (Tamungang \& Cheke, 2012). This also poses a threat to the parrot population.

The parrots are transported in large numbers inside the baskets or in boxes containing several dozen birds. Many of these animals die during capture, transport and export. Mortality of this species, from capture to export, is estimated in the DRC at $40-50 \%$ (Fotso, 1998b) and 10 50\% (Hart, 2013), 60 - 66\% in Nigeria (McGowan, 2001), up to 50\% in Guinea / Guinea-Bissau (Clemmons, 2003) and in Cameroon, 30 - 50\% (Fotso, 1998a). This is a major waste and a threat to the population of grey parrots.

This transportation is most often done overnight using vehicles or motorcycles. It is also carried out during the day by legal operators and some illegal immigrants who transport birds in small numbers inside bags or boxes. The marketing circuit in the study area is increased by the existence of many abandoned forest tracks (by loggers) easily passable by motobike. These tracks facilitate the transport of illegally caught parrots to Gabon and Equatorial Guinea, but also to Sangmelima and Ebolowa, cities from which they are routed to other metropolitan towns of Cameroon.

\subsection{Impact of Deforestation on the Disappearance of Nests in the Study Area}

Most residents believe that global deforestation has a significant effect on the population, the distribution of nests and their abundance in the study area.

However, its impact on the grey parrot population varies with the type of deforestation. According to residents, mechanized logging is the one that causes more damage to the parrot population compared to other types of deforestation (mining, agriculture and artisanal logging). In addition, the volumes of wood harvested informally for local markets, firewood and charcoal production can greatly exceed those of industrial production; for example, the volume 
of forest used for fuelwood production in the DRC is 200 times that of the production of wood used for commercial purposes (FAO, 2012). Agricultural expansion and, to a lesser extent, shifting farming are also important potential drivers of forest loss, although their overall contribution is a source of debate (Ickowitz et al., 2015).

Estimates of changes in the availability of suitable habitat for $P$. erithacus have not been made, however data on overall forest loss show a rough indication of trends affecting populations (CITES 2016). Many recent studies show that the rate of forest loss in the Congo Basin is increasing (Ickowitz et al., 2015). Ernst et al. (2012) reported that gross deforestation rates for Cameroon, Congo, Gabon, Equatorial Guinea, Central African Republic and the Democratic Republic of Congo (DRC) have doubled from $0.13 \%$ to $0.26 \%$ per year between 1990 - 2000 and 2000 - 2005. During the same period, gross degradation rates in dense forest areas also doubled from $0.07 \%$ to $0.14 \%$. As the grey parrot is a species closely associated with tropical forests, their disappearance and fragmentation lead to the destruction of nests and the scarcity of food resources (Tamungang \& Cheke, 2012; Tamungang et al., 2013). This has a direct influence on the success of nesting and the survival of the species which depend on the cavities formed naturally in the trunks of trees.

\section{Conclusion}

At the end of our work which aimed to assess the impact of human activities on the survival and conservation of grey parrots in the KNP-MGS complex, it appears that several human activities threaten the survival of these birds. The greatest threats lie in the commercialization of this avifauna and mechanized logging. The first deprives the fledglings of maternal care when they are taken during the breeding period, the second most dangerous, kills the fledglings, considerably reduces the number of nests in the natural environment and the drastic reduction in the number of reproducers, this which has a short and long term impact on the evolution of the parrot population, since parrots do not build nests, depend closely on the cavities formed naturally in the trunks and branches of large forest trees. On the other hand, the local populations through subsistence farming and artisanal logging, seem to have a very small negative impact on the nesting and conservation of grey parrots. However, to ensure a long-term survival of this bird species, strict compliance with regulations prohibiting catches of parrots these days, raising awareness among local residents and improving their standard of living would significantly contribute to the conservation of grey parrots in the complex.

\section{Aknowledgement}

Thanks to the financial support of PARROTPRO (Cameroon Parrot Project), to the authorities of Oveng Sub-Division, the Conservator of Kom National Park-Mengame Gorilla Sanctuary Complex (Mr Zang Mbarga), Eco-guards, Rural Communities for their services and hospitality. Immense thanks for the logistic support from the staff of the research unit of Biology and Applied Ecology (LABEA), Department of Animal biology of the University of Dschang, Cameroon. 


\section{References}

Aktouf, O. (1987). Méthodologie des sciences sociales et approche qualitative des organisations. Une introduction à la démarche classique et une critique. Montréal: Les Presses de l'Université du Québec, Montréal.

Annorbah, N. N. D. (2016). Collar NJ and Marsden SJ. Trade and habitat change virtually eliminate the Grey Parrot Psittacus erithacus from Ghana. Ibis, 158, 82-91. https://doi.org/10.1111/ibi.12332

CITES. Examen des propositions d'amendement des annexes I et II (cas de Psittacus erithacus). Dix-septième session de la Conférence des Parties Johannesburg (Afrique du Sud), 2016,19 .

Collar, N., Kirwan, G. M., \& Sharpe, C. J. (2016). Grey Parrot (Psittacus erithacus). In Del Hoyo, J., Elliott, A., Sargatal, J., Christie, D. A. \& de Juana, E. (Eds.), Handbook of the Birds of the World Alive. Lynx Edicions, Barcelona.

Del Hoyo, J., \& Collar, N. J. (2014). HBW and Bird Life International Illustrated Checklist of the Birds of the World, Volume 1: Non-passerines. Barcelona: Lynx Edicions.

Durand, C., Tanguay, I., \& Vachon, S. (1997). La gestion de la méthodologie dans les firmes de sondage au Québec et au Canada. 65 ${ }^{\text {ème }}$ Congrès de l'ACFAS, Université du Québec à Trois-Rivières.

Ernst, C., Mayaux, P., Verhegghen, A., Bodart, C., \& Christophe, M. (2012). t Defourny P. National Forest Cover Change in Congo Basin: Deforestation, Reforestation, Degradation and Regeneration for the years 1990, 2000 and 2005. Global Change Biology, 19(4), 1173-1187. https://doi.org/10.1111/gcb.12092

FAO. (2012). FAOSTAT. http://faostat3.fao.org/home/index.html, Rome. 12 october, 2012.

Fotso, R. (1998a). Survey statut of the distribution and utilization of the grey parrot (Psittacus erithacus) in Cameroon. Unpublished report to CITES.

Fotso, R. (1998b). Etude sur l'état, la répartition géographique et l'utilisation du perroquet gris (Psittacus erithacus) dans la République démocratique du Congo. CITES, Geneva, Switzerland. Unpublished report to CITES.

Guesdon, C. T. M. (2010). Les Psittacidés et les pathologies dues à leur captivité. Thèse de Doctorat, Ecole Nationale Vétérinaire d'Alfort, France.

Hart, J. (2013). Summary Analysis of the Trade Chain and controls in African Grey Parrot in Orientale and Maniema Province, DR-Congo. In: Strengthening Capacity for Monitoring and Regulation of International Trade of African Grey Parrot, Final Report to CITES.

Ickowitz, A., Slayback, D., Asanzi, P., \& Nasi R. (2015). Agriculture and deforestation in the Democratic Republic of the Congo: A synthesis of the current state of knowledge. Occasional Paper 119. Bogor, Indonesia: CIFOR. 
Israel, G. D. (2012). Determining Sample Size, Agricultural Education and Communication Department, Florida Cooperative Extension Service, Institute of Food and Agricultural Sciences, University of Florida.

Kougoum, P. G. N. (2017). Tamungang SA and Téguia A. Breeding biology of African grey parrot (Psittacus erithacus) in Kom National Park (South-Cameroon) and implications to the species conservation. International Journal of Biological and Chemical Sciences, 11(5), 1948-1966. https://doi.org/10.4314/ijbcs.v11i5.2

May, D. L. (2001). Grey Parrots in the Congo Basin Forest. Psittacene, 13(47), 2-3.

Ngenyi, A. (2002). African grey parrot trade in Cameroon. Psittascene, 14, 2-3.

Ngoufo, R., Njoumemi, N., \& Parren, M. (2012). État des lieux de la situation économique, écologique et sociale actuelle de l'espace Camerounais du TRIDOM. Tropenbos International - Programme du bassin du Congo, Wageningen, Pays-Bas.

Nkongmeneck, B. A., Tsabang, N., Fongnzossie, E., Balouma, J. M., Apalo, P., Halford, M., \& Kamou, E. (2003). Etude Botanique du Sanctuaire à Gorilles et Chimpanzés de Mengame (Sud-Cameroun): Ressources ligneuses, Faciès de Végétation, Dégré de pertubation et sous-bois. Rapport technique No 4

Pepperberg, I. M. (1990). Cognition in an African grey parrot (Psittacus erithacus): Further evidence for comprehension of categories and labels. Journal of Comparative Psychology, 104, 41-52. https://doi.org/10.1037/0735-7036.104.1.41

Pepperberg, I. M. (2001). Avian cognitive abilities, Bird Behaviour, 14, 51-70.

Pepperberg, I. M. (2006a). Cognitive and communicative abilities of Grey parrots, Applied Animal Behaviour Science, 100, 77-86. https://doi.org/10.1016/j.applanim.2006.04.005

Pepperberg, I. M. (2006b). Grey parrot (Psittacus erithacus) Numerical abilities: Addition and further experiments on a zero-like concept. Journal of Comparative Psychology, 120, 1-11. https://doi.org/10.1037/0735-7036.120.1.1

Pepperberg, I. M. (2007). Individual differences in Grey Parrots (Psittacus erithacus): effects of training. Journal of Ornithology, 148(2), 16-168. https://doi.org/10.1007/s10336-0070162-0

Tamungang, S. A., Ayodele, I. A., \& Akum, Z. E. (2002). Basic home range characteristics from the conservation of the African grey parrot in the Korup national park, Cameroon. Journal of the Cameroon Academy of Science, 1(3), 155-160.

Tamungang, S. A., \& Cheke, R A. (2012). Population status and management plan of the African grey parrot (Psittacus erithacus) in Cameroon. Full report prepared by MINFOF for CITES Secretariat, Geneva, Switzerland. 
Tamungang, S. A., Cheke, R. A., Kougoum, P. G., \& Ntiri, S. E. (2013). Linking population size to conservation needs of the Grey Parrot in Cameroon. International Journal of Biodiversity and Conservation, 5(8), 478-485.

CITES. (2004). AC22 Doc. 10.2 Annexe 1. Etat de conservation des perroquets gris à queue rouge dans le monde.

UNEP-WCMC. (2004). Review of significant trade. Analysis of trade trends with notes on the conservation status of selected species. Annexe B: Birds. Unpublished report to CITES.

UNEP-WCMC CITES. (2007). Trade data base, 2007.

\section{Copyrights}

Copyright for this article is retained by the author(s), with first publication rights granted to the journal.

This is an open-access article distributed under the terms and conditions of the Creative Commons Attribution license (http://creativecommons.org/licenses/by/4.0/) 